\title{
NON- AND LOW-ALCOHOLIC BEER - POPULARITY AND MANUFACTURING TECHNIQUES
}

\author{
Rafał Kozłowski ${ }^{1}$, Marcin Dziedziński ${ }^{1}$, Barbara Stachowiak ${ }^{2 \varpi}$, \\ Joanna Kobus-Cisowska ${ }^{1}$ \\ ${ }^{1}$ Department of Gastronomy Sciences and Functional Foods, Poznań University of Life Sciences \\ Wojska Polskiego 31, 60-624 Poznań, Poland \\ 2Department of Technology of Plant Origin Food, Poznań University of Life Sciences \\ Wojska Polskiego 31, 60-624 Poznań, Poland
}

\begin{abstract}
Beer is one of the most popular alcoholic beverages around the world. Currently, there is a noticeable increase in the consumption of beer, especially non- and low-alcoholic beers. The sensory characteristics of these beers are very similar to their alcoholic counterparts, while a lack of alcohol or a low alcohol content reduces their psychoactive character. In addition, their high nutritional and low caloric values make these types of drinks an excellent alternative to soft drinks (for adults), primarily sweetened carbonated beverages. The aim of this study was to characterize the non- and low-alcoholic beer market and the techniques for manufacturing these products. In general, reducing alcohol content is possible through the use of biological methods (limiting fermentation processes) and physical methods (dealcoholization processes). An example of a biological method is the modification of the mashing program in order to reduce the level of fermentable sugars in wort, e.g., inactivation of $\beta$-amylase, or the use of unconventional yeasts with limited ability or inability to convert fermentable sugars into alcohol. The group of physical methods includes modern thermal and membrane separation techniques which enable the efficient removal of ethanol from beer to the desired level. This paper also presents the nutritional value of regular and non-alcoholic beers and their antioxidant potential. The prohealth properties of beer were pointed out, emphasizing the negative influence of alcohol on the human body. The collected information shows that the market of non-alcohol and low-alcohol beers will continue to grow. The main directions of its development will concern the production of functional beers.
\end{abstract}

Keywords: beer, non-alcoholic beer, low-alcoholic beer, beer market, brewing

\section{INTRODUCTION}

Beer is one of the oldest alcoholic beverages. Its production was known as early as around 4,000 BC in the Middle East (Violino et al., 2020). Later, beer was produced in Greece and ancient Rome, where it was not particularly appreciated. The medieval period saw an increase in the popularity of this drink in northern and northeastern Europe (Sohrabvandi et al., 2010). These days, beer has gained popularity all over the world, and the 7th of August is celebrated as International Beer Day.

Nowadays, a dynamic development of the non- and low-alcoholic beer (NAB and LAB) industry has been observed around the world. However, there are differences in the definition of NAB in individual countries related to the permissible alcohol content. In Poland, similarly to most European Union countries, the legal

\footnotetext{
『barbara.stachowiak@up.poznan.pl
} 
Kozłowski, R., Dziedziński, M., Stachowiak, B., Kobus-Cisowska, J. (2021). Non- and low-alcoholic beer - popularity and manufacturing techniques. Acta Sci. Pol. Technol. Aliment., 20(3), 347-357. http://dx.doi.org/10.17306/J.AFS.2021.0961

alcohol content in $\mathrm{NAB}$ is up to $0.5 \%$ by volume, but it is up to $1 \%$ by volume in Spain and $1.2 \%$ by volume in France. When it comes to the United States, the content is up to $0.05 \%$ by volume. In Islamic countries such as Saudi Arabia and the United Arab Emirates, where alcohol consumption is prohibited by law, NAB contains less than $0.1 \% \mathrm{v} / \mathrm{v}$ of alcohol and provide an alternative to other soft drinks (Muller et al., 2020; Ustawa..., 1982). On the other hand, there are no regulations defining what low-alcoholic beer is. In Poland, this name has meaning only in a marketing sense. In general, on the Polish market, the alcohol content in $\mathrm{LAB}$ is in the range of 0.5 to $3.5 \% \mathrm{v} / \mathrm{v}$.

In Europe, the increase in $\mathrm{NAB}$ and $\mathrm{LAB}$ consumption is an effect of the changing profile of the main beer consumer (aging of the population), who is interested in a healthy and active lifestyle, is more and more demanding, is focused on high quality functional products and limits stimulants (including alcohol) (Kowalczuk et al., 2017; Pielak et al., 2019; 0\% alkoholu..., 2020). It is worth underlining that the category of NAB and LAB includes attractive products with high sensory and nutritional value, with a lower energy value compared to alcohol-containing beers (Table 1). For example, the average energy value of the most popular lagers on the market is close to 92 $\mathrm{kcal}$, whereas for NAB it is only $37 \mathrm{~kJ} / 100 \mathrm{ml}$. Moreover, NAB is relatively inexpensive compared to other types of alcoholic beverages.

Beer is also gaining increasing interest for its potential health-promoting properties. It is a source of easily absorbed protein hydrolysis products, vitamins and minerals, providing a broad spectrum of health benefits (Vanderhaegen et al., 2003). Beer also has antioxidant properties (Table 2), mainly due to polyphenols. Their concentration in beer differs and strongly depends on the kind of malt and hops used in production. About $70-80 \%$ of the total polyphenols in beer originate from malt and unmalted cereals used in mashing. Another source of these is hops (Habschied et al., 2020).

The most important hop polyphenols are prenyl chalcones (xanthohumol and desmethylxanthohu$\mathrm{mol}$ ), as well as their isomeration products - isoxanthohumol and 8-prenylnaringenin respectively, which are formed at high temperatures during wort boiling with hops (Jaskula-Goiris et al., 2014). The presence
Table 1. Mean nutrient composition of regular and nonalcoholic beer

\begin{tabular}{|c|c|c|}
\hline \multirow[b]{2}{*}{ Nutrient } & \multicolumn{2}{|c|}{ Mean content, $\mathrm{g} / 100 \mathrm{~g}$} \\
\hline & $\begin{array}{l}\text { in regular } \\
\text { beer }\end{array}$ & $\begin{array}{l}\text { in non- } \\
\text { alcoholic } \\
\text { beer }\end{array}$ \\
\hline \multicolumn{3}{|l|}{ Proximates } \\
\hline Energy, Kcal & 91.97 & 37.00 \\
\hline Protein, g & 0.46 & 0.20 \\
\hline Total lipid (fat), g & 0.00 & 0.10 \\
\hline Saturated fatty acids, g & 0.00 & 0.00 \\
\hline Monounsaturated fatty acids, $g$ & 0.00 & 0.00 \\
\hline Polyunsaturated fatty acids, $g$ & 0.00 & 0.00 \\
\hline Cholesterol, mg & 0.00 & 0.00 \\
\hline Carbohydrate, by difference, $g$ & 3.55 & 8.00 \\
\hline Fiber, total dietary, $\mathrm{g}$ & 0.00 & 0.00 \\
\hline \multicolumn{3}{|l|}{ Minerals } \\
\hline Calcium (Ca), mg & 4.00 & 7.00 \\
\hline Copper $(\mathrm{Cu}), \mathrm{mg}$ & 0.01 & 0.01 \\
\hline Iron $(\mathrm{Fe}), \mathrm{mg}$ & 0.02 & 0.01 \\
\hline Magnesium (Mg), mg & 6.00 & 7.00 \\
\hline Manganese (Mn), mg & 0.02 & 0.01 \\
\hline Silicon (Si), mg & 1.92 & nd \\
\hline Selenium (Se), mg & 0.60 & 1.20 \\
\hline Fluoride (F), mg & 44.20 & nd \\
\hline Phosphorus (P), mg & 14.00 & 16.00 \\
\hline Potassium (K), mg & 27.00 & 8.00 \\
\hline Sodium (Na), mg & 4.00 & 13.00 \\
\hline Zinc (Zn), mg & 0.01 & 0.02 \\
\hline \multicolumn{3}{|l|}{ Vitamins } \\
\hline Vitamin $\mathrm{C}$, total ascorbid acid, mg & 0.00 & 0.50 \\
\hline Thiamin B1, mg & 0.01 & 0.00 \\
\hline Riboflavin B2, mg & 0.03 & 0.00 \\
\hline Niacin B3, mg & 0.51 & 1.11 \\
\hline Pantothenic acid B5, mg & 0.04 & 0.04 \\
\hline Vitamin B6, mg & 0.05 & 0.03 \\
\hline Folate, DFE, $\mu \mathrm{g}$ & 6.00 & 14.00 \\
\hline Choline, total, mg & 10.10 & 10.10 \\
\hline Cobalamin B12, $\mu \mathrm{g}$ & 0.00 & 0.02 \\
\hline
\end{tabular}

nd - no data available.

Source: based on USDA (2019a), USDA (2019b). 
Kozłowski, R., Dziedziński, M., Stachowiak, B., Kobus-Cisowska, J. (2021). Non- and low-alcoholic beer - popularity and manufacturing techniques. Acta Sci. Pol. Technol. Aliment., 20(3), 347-357. http://dx.doi.org/10.17306/J.AFS.2021.0961

Table 2. Antioxidant capacity of beer

\begin{tabular}{lcl}
\hline \multicolumn{1}{c}{ Parameter } & Range & \multicolumn{1}{c}{ References } \\
\hline Total polyphenols (FC method), mg GAE/L & $127-855$ & $\begin{array}{l}\text { Zhao et al. (2010), Pietro and Bamforth (2011), Mikyška and Dušek } \\
\text { (2019), Wannenmacher et al. (2019), Habschied et al. (2020) }\end{array}$ \\
Total anthocyanogens, mg/L & $19.0-84.5$ & Mikyška and Dušek (2019), Wannenmacher et al. (2019) \\
Antioxidant activity; DPPH, mmol TE/L & $0.55-6.67$ & Floridi et al. (2003), Martínez et al. (2017), Habschied et al. (2020) \\
Antioxidant activity; FRAP, mmol TE/L & $0.862-1.271$ & Wannenmacher et al. (2019) \\
\hline
\end{tabular}

of these compounds in the final beers is at the level of $40-3440 \mu \mathrm{g} / \mathrm{L}$ for isoxanthohumol, and $1-240 \mu \mathrm{g} / \mathrm{L}$ and $43-4000 \mu \mathrm{g} / \mathrm{L}$ for 8-prenylnaringenin and desmethylxanthohumol, respectively. Beer polyphenols have antioxidant, anti-inflammatory, anti-cancer and anti-angiogenic effects (Kołota et al., 2014). Due to the content of bioactive compounds, hops and preparations based on it are increasingly used as components in teas, functional infusions with sedative, pain relief, and anti-inflammatory properties (Dziedziński et al., 2020). The antioxidant potential of beer can be significantly increased by the addition of preparations containing antioxidants, i.e., fruit or herb extracts, e.g., Cornelian cherry fruits (Kawa-Rygielska et al., 2019), dried goji berries, lemon balm, thyme, and green tea (Gościnna et al., 2019). Currently, fruit juices with a proven antioxidant effect are also a popular addition to beer, e.g., citrus, raspberry, chokeberry, blackcurrant, elderberry juices. Beers with increased xanthohumol content have also been developed, such as the Czech Žatec or the German XAN Hefe-Weisbier.

Studies indicate that moderate consumption of beer has a significant impact on health, such as reducing the risk of cardiovascular disease, diabetes, osteoporosis, dementia, and lowering blood cholesterol levels (Salanţă et al., 2018). But the potential health benefits of moderate beer consumption are limited by the negative consequences of alcohol intake and energy content (de Gaetano et al., 2016). Thus, only $\mathrm{NAB}$ and $\mathrm{LAB}$ create the possibility of the development of the beer industry towards the production of functional beers. In addition, NAB may be subject to health claims suggesting a positive effect on health. At present, alcohol-free isotonic beers (with the addition of electrolytes), revitalizing ones (with the addition of electrolytes and vitamins), energy drinks (with the addition of caffeine) or the aforementioned beers with increased antioxidant activity, and even beers containing probiotics, are already available on the Polish market.

The aim of this study was to characterize the low and non-alcoholic beer market and the techniques for manufacturing these products. In general, the reduction in alcohol content is made possible through the prevention of its formation (biological methods) or removing alcohol from the final beer product (physical methods) (Mellor et al., 2020).

\section{MARKET BEER CHARACTERIZATION}

According to the Kirin Beer University Report, world beer consumption in 2019 was $189.054 \mathrm{mln} \mathrm{kL}$. Asia had the largest share of world beer consumption (33\%), where China was the leader (with total beer consumption of $39.22 \mathrm{mln} \mathrm{kL}$, which accounts for $20.7 \%$ of world beer consumption). Europe comes second (26.4\%), followed by Central and South America (17.3\%) (Kirin Holdings Company, 2020). Poland ranks 11th in the global ranking of beer consumption in general and 5th in beer consumption per capita. In the Czech Republic, beer consumption per capita remains the highest (Table 3 ).

In 2019, the production of alcohol-containing beer in the European Union exceeded 34 billion liters. The share of Poland in the production of beer in the EU was $11 \%$ (3.9 bn liters). According to Eurostat (2020), Poland and Spain are the largest beer producers in EU after Germany. In addition, in 2019 the EU produced 1.4 billion liters of beer which contained less than $0.5 \%$ alcohol or had no alcohol content at all (Eurostat, 2020).

In Poland, the industry of non-alcoholic beer has remained at a very high level for several years. It grew the most in 2019 (September 2019 vs. September 
Kozłowski, R., Dziedziński, M., Stachowiak, B., Kobus-Cisowska, J. (2021). Non- and low-alcoholic beer - popularity and manufacturing techniques. Acta Sci. Pol. Technol. Aliment., 20(3), 347-357. http://dx.doi.org/10.17306/J.AFS.2021.0961

Table 3. Beer consumption in different countries

\begin{tabular}{|c|c|c|c|}
\hline $\begin{array}{c}\text { Place } \\
\text { in the ranking }\end{array}$ & Country & L per capita & $\begin{array}{c}\text { Total national consumption } \\
\text { thous. } \mathrm{kL}\end{array}$ \\
\hline 1 & Czech Republic & 188.60 & 1,999 \\
\hline 2 & Australia & 107.80 & 949 \\
\hline 3 & Romania & 100.30 & 1,956 \\
\hline 4 & Germany & 99.00 & 8,160 \\
\hline 5 & Poland & 97.70 & 3,713 \\
\hline 6 & Namibia & 95.50 & 248 \\
\hline 7 & Ireland & 92.90 & 446 \\
\hline 8 & Spain & 88.80 & 4,119 \\
\hline 9 & Croatia & 85.50 & 351 \\
\hline 10 & Latvia & 81.40 & 155 \\
\hline 11 & Estonia & 80.50 & 105 \\
\hline 12 & Slovenia & 80.00 & 168 \\
\hline 13 & Netherlands & 79.30 & 1,357 \\
\hline 14 & Bulgaria & 78.70 & 551 \\
\hline 15 & Panama & 78.30 & 329 \\
\hline 16 & Slovak Republic & 76.10 & 418 \\
\hline 17 & Australia & 75.10 & 1,885 \\
\hline 18 & Lithuania & 74.40 & 216 \\
\hline 19 & Hungry & 73.70 & 715 \\
\hline 20 & USA & 72.70 & 23,920 \\
\hline 21 & Finland & 72.00 & 403 \\
\hline 22 & Mexico & 70.50 & 9,324 \\
\hline 23 & United Kingdom & 70.30 & 4,712 \\
\hline 24 & Bosnia and Herzegovina & 68.60 & 240 \\
\hline 25 & Gabon & 67.00 & 141 \\
\hline 26 & Belgium & 65.90 & 765 \\
\hline 27 & New Zealand & 61.00 & 293 \\
\hline 28 & Denmark & 59.80 & 347 \\
\hline 29 & Cambodia & 59.20 & 976 \\
\hline 30 & Brazil & 58.40 & 12,401 \\
\hline 31 & Russia & 57.70 & 8,306 \\
\hline 32 & Switzerland & 55.10 & 476 \\
\hline 33 & Portugal & 54.90 & 565 \\
\hline 34 & Congo Republic & 54.80 & 302 \\
\hline 35 & Canada & 53.50 & 1,994 \\
\hline
\end{tabular}

Source: based on Kirin Holdings Company (2020). 


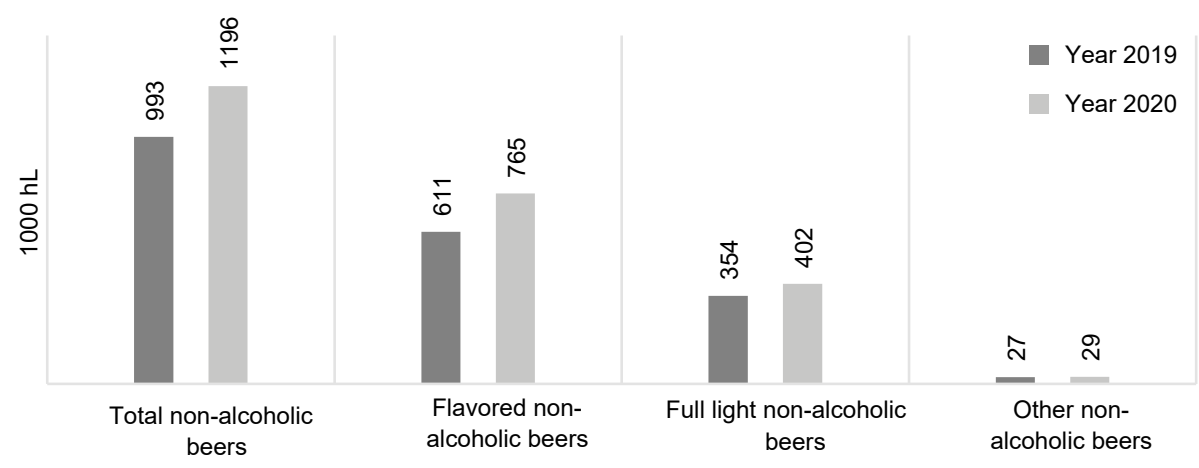

Fig. 1. Sales volume of non-alcoholic beers in Poland in $1000 \mathrm{hL}$ Source: based on $0 \%$ alkoholu... (2020).

2018) by nearly $60.8 \%$ by volume and $63.0 \%$ by value; for the corresponding period in 2020 - due to COVID - growth was smaller but still in double digits $-20.5 \%$ by volume and $24.7 \%$ by value. In 2019 the non-alcoholic beer industry accounted for $4.9 \%$ of the beer market volume, and the NAB $(0 / 0 \%)$ share was as much as $89 \%(0 \%$ alkoholu..., 2020).

It should be emphasized that in Poland within the NAB segment, three sectors can be distinguished: nonalcoholic lagers, non-alcoholic flavored beers, and non-alcoholic beer specialties, e.g., $0 \%$ wheat beers, $0 \%$ IPA beers, etc. The non-alcoholic beer specialties sector is the smallest, while the biggest is the sector of flavored beers, which are successfully replacing soft drinks - mainly carbonated beverages (Fig. 1).

Brewers are trying to adapt to consumer expectations and are offering a wide selection of beers with reduced alcohol content while maintaining the other highly desirable characteristics of the product (Bellut et al., 2020; Rošul et al., 2019). Consumers, in fact, are looking for products as close as possible to conventional types, taking into account sensory properties, especially in terms of taste qualities (Ignat et al., 2020). In addition, the producers tend to provide consumers with beers as alternatives to other beverages that could be consumed before or during daily activities (driving or operating machinery, playing sports) or under certain conditions (pregnancy, taking medication). Finally, the increase in NAB is the result of allowing such products into markets in countries where alcohol consumption is prohibited due to religious reasons.
Indicators for the volume of sales of LAB were initially low, while this segment of the beer industry is currently growing (Brányik et al., 2012). The global $\mathrm{NAB}$ and $\mathrm{LAB}$ market has seen a combined volume growth of $20 \%$ and is expected to grow even further by another $24 \%$ by the end of 2021 . Countries in the Middle East, Africa, and Western Europe are the largest markets in terms of volume and value for $\mathrm{NAB}$ and LAB (Bellut et al., 2020).

\section{TECHNIQUES FOR REDUCING ALCOHOL IN BEER}

Beer is considered the most complex fermented beverage in the world. Generally, beer production is divided into two stages, which are (1) making of the pitching wort from malt and hops and (2) alcoholic fermentation using yeast. Wort making includes mashing the crushed malt, filtration, brewing (boiling the wort with hops) and then cooling it. The next stage is the fermentation with yeast, which results in the so-called young/ green beer that, after a stage of maturation and colloidal stabilization, is poured into unit packages (the filling stage). Beer is preserved by pasteurisation (before or after filling) or microfiltration. Manufacturing techniques are being upgraded and modified all the time and now make it possible to manufacture beer in an efficient, effective, and economical way (de Moura and dos Santos Mathias, 2018). Methods for manufacture of LAB and NAB have undergone dynamic development in recent decades. The simplest way to reduce the alcohol content of beer is to introduce lemonade 
(usually citrus) or other non-alcoholic drinks. In Poland, these types of products are called Radlers and contain alcohol at the level of $2.6 \%$ vol. Radlers are usually made on the basis of light beer, and the addition of lemonade soothes the feeling of bitterness (Woźniak, 2013). Other methods to obtain non- or low-alcohol content in beer include biological methods (limiting fermentation processes) and physical methods (dealcoholization processes) (Salanță et al., 2020).

\section{Biological methods}

The biological methods of NAB and LAB production are most often associated with the reduction of the fermentation potential of the wort and/or the limitation of the fermentation process carried out using classic brewing yeast. The fermentation potential of the wort can already be decreased at the stage of the mashing process by limiting the decomposition of starch to low molecular weight fermentable sugars such as maltose and glucose. This effect can be obtained, for example, by inactivating the $\beta$-amylase enzyme sensitive to temperatures above $65^{\circ} \mathrm{C}$. The low fermenting extract of the wort can also be obtained by using unmalted raw materials, such as corn or rice for beer production, or by extracting the spent grain with cold water (Muller et al., 2020).
The second solution involves an interruption of the fermentation process. This approach is probably the most popular way to make LAB and NAB. After reaching an alcohol concentration of $0.5 \%$ by volume, the fermentation process can be stopped by removing the yeast by filtration, centrifugation, or pasteurization. Such beer has a sulfuric flavor which is removed during maturation. Another solution is to interrupt the fermentation by rapidly cooling the wort or to limit the fermentation by carrying it out at a low temperature. The wort is not oxygenated, which limits the yeast proliferation and prolongs the lag phase during which yeasts metabolize sugars, producing compounds that affect taste and reduce carbonyl compounds (responsible for the "wort" taste), but do not produce alcohol (Montanari et al., 2008).

An interesting solution used for the production of $\mathrm{LAB}$ is the reduction of the contact time between the yeast and the wort during fermentation, which can be obtained by a slow, continuous flow of the wort over the immobilized yeast, known as the immobilized yeast technique (Szollosi et al., 2016).

Other methods to produce NAB and LAB are associated with the use of yeast strains that ferment poorly or do not ferment the sugars present in wort (Table 4). Saccharomyces ludwigii is most often used

Table 4. Effects of unconventional yeast on production of innovative beers

\begin{tabular}{ll}
\hline \multicolumn{1}{c}{ Yeast group } & \multicolumn{1}{c}{ Effects for beer } \\
\hline $\begin{array}{l}\text { Dekkera/Brettanomyces } \\
\text { Wickerhamomyces anomalus }\end{array}$ & - ester production (fruity or floral character); $\beta$-glucosidase activity \\
& - production of ethyl acetate, ethyl propanoate, phenyl ethanol, and 2-phenylethyl \\
acetate (fruity aroma) & - production of 2-phenylethanol and amyl alcohols (fruity and floral aroma) \\
Torulaspora delbrueckii & - production of lactic acid (flavor and mouthfeel) \\
Lachancea thermotolerans & \multicolumn{1}{c}{ Alcohol reduction yeast } \\
\hline & - low fermentation activity in maltose and maltotriose \\
\hline $\begin{array}{l}\text { Saccharomycodes ludwigii } \\
\text { Torulaspora delbrueckii }\end{array}$ & - inability to ferment maltose and maltotriose \\
Pichia kluyveri & - limited ability to ferment glucose \\
Zigosaccharomyces rouxii & Cotal or partial inability to ferment maltose \\
\hline & Calorie reduction yeast \\
\hline Saccharomyces cerevisiae var. diastaticus & - glucoamylase activity (digestion of dextrins) \\
Dekkera/Brettanomyces & $-\beta$-glucosidase activity (degradation of dextrins) \\
\hline
\end{tabular}

Source: based on Capece et al. (2018), Holt et al. (2018). 
for this purpose. This strain does not produce invertase or maltase, and for this reason is unable to ferment maltose or maltotriose, but only glucose, fructose, and sucrose (Michel et al., 2016). The final beer is sweet (Brányik et al., 2012). In studies, Torulaspora delbrueckii have shown a substantial, almost $50 \%$ reduction in the ethanol content that was accompanied by a pleasant and valuable sensorial profile (Canonico et al., 2016). Pichia kluyveri can be used for producing $\mathrm{LAB}$ or $\mathrm{NAB}$ due to its limited ability to ferment glucose whilst significantly changing hop compounds into positive flavor compounds. Zigosaccharomyces rouxii is considered suitable for producing fermented beverages with low-alcohol content because of its total or partial inability to ferment maltose (Capece et al., 2018; De Francesco et al., 2015).

The biological methods of NAB and LAB production are carried out using the same equipment as traditional beer production but require accurate and rapid analytical control. The disadvantage of these methods is the limited fermentation time, which is insufficient for completing the conversion of wort to beer. This can result in a final product with low beer aroma compounds but strong wort characteristics. In order to correct the sensory characteristics, appropriate flavorings are added to each type of beer, e.g., isoamyl acetate (banana aroma). Moreover, beer produced in this way must be pasteurized to ensure safety. This prevents a second fermentation in the package, which could cause a significant increase in pressure and even rupture the bottle or can (Eßlinger, 2009; Puerari et al., 2016; Saison et al., 2010).

\section{Physical methods}

The physical methods rely on the removal of alcohol from beer at the end of the production process. This requires additional financial outlays associated with the purchase of alcohol removal installations. Unfortunately, regardless of the technique used, it is associated with a loss of taste, the feeling of fullness and the freshness of the beer (Muller et al., 2020).

The group of physical methods includes thermal processes and membrane separation processes.

\section{Thermal processes}

The need to keep beer at an elevated temperature (at least $60^{\circ} \mathrm{C}$ ) for a long time causes irreversible unfavorable changes, such as darkening, caramelization of residual sugars and degradation of compounds responsible for the aroma (Montanari et al., 2008). Moreover, volatile flavor compounds (higher alcohols and esters) and bitterness are removed together with the distillate (Burger and Zarnkow, 2009). With modern technologies such as falling film evaporation, vacuum distillation, and thin layer evaporation, it is possible to lower the boiling point of ethanol, shorten the evaporation time and have a high degree of distillate separation. Moreover, by using evaporators, it is possible to lower the alcohol concentration even to about $0.03 \% \mathrm{v} / \mathrm{v}(0 \%$ alkoholu..., 2020).

The falling film evaporation technique involves the use of an integrated process to separate liquid mixtures by diffusion distillation while evaporating a film of liquid flowing down a vertical wall. The beer is precooked in a vacuum. In an even, thin layer, it enters the heating pipes through the distribution device. It then flows downward gravitationally at the boiling point, while the vapor moves in the same direction (co-current flow). This process lasts only a few seconds. The vapor separator receives and condenses alcohol-rich vapors from non-alcoholic beer concentrate for further condensation. This technology is very popular due to the high efficiency of the process (Montanari et al., 2008).

$\mathrm{NAB}$ and $\mathrm{LAB}$ can also be obtained by vacuum distillation. As a result, alcohol can be removed from beer even at $35^{\circ} \mathrm{C}$ (usually at $42-48^{\circ} \mathrm{C}$ ) instead of around $78^{\circ} \mathrm{C}$, as is the case at normal pressure. The volatile aromas and carbon dioxide collected earlier in a vacuum degasser are condensed (they can be redistilled for better concentration) and are reintroduced into the dealcoholized beer. This method makes it possible to obtain beer with a clean, distinctive hop flavor and a content of less than $0.05 \%$ alcohol (Salanță et al., 2020).

In a thin layer centrifugal evaporator, the alcohol is evaporated at $35-60^{\circ} \mathrm{C}$. The beer is instantly distributed over the heated wall of the evaporator in an extremely thin layer (approximately $0.1 \mathrm{~mm}$ ). The feeding layer of beer is subjected to centrifugal force, whose value is more than one hundred times greater than gravity. Therefore, the transfer ability of beer on the heating surface is greatly improved, and the residence time on the heating surface is short (usually 1 second). This process reduces the destruction of the 
heat-sensitive components of the beer, which helps to preserve the original color and aroma. The aromatic vapors removed from the beer are transferred to an external condenser and may be reintroduced into the dealcoholized beer. With this technique, the alcohol content of the beer can be lower than $0.05 \% \mathrm{v} / \mathrm{v}$ (Brányik et al., 2012; Muller et al., 2020; Salanță et al., 2018).

\section{Membrane separation processes}

Membrane processes use semi-permeable membranes through which selected solutes or solvent selectively migrate (permeate). As a result, the composition of the solution changes as it passes through the so-called membrane module. For the dealcoholization of beer, dialysis, reverse osmosis, and pervaporation are used.

Reverse osmosis is a forced process (it requires external energy in the form of pressure that is higher than osmotic pressure) which permeates the membrane with solvent rather than solutes. Due to external energy, the movement of the liquid is towards the less concentrated solution. The reverse osmosis process requires the filtered beer to flow tangentially to the membrane surface. Ethanol and water permeate the membrane selectively. The process consists of three stages: (1) the concentration phase, in which the permeate, consisting of alcohol, water, $\mathrm{CO}_{2}$ and aromatics, is removed from the beer, apparently increasing the alcohol content (beer volume decreases); (2) the diafiltration phase, when the quantitatively demineralised water replaces the previously removed permeate; (3) the last phase, in which the demineralised water replenishes the retentate (beer) to its initial volume, further reducing the alcohol content (Montanari et al., 2008).

During the production of NAB, the dialysis process involves the use of a semi-permeable membrane that separates the beer and the dialysate (aqueous solution), which flows in countercurrent. The contact time and concentration gradient at the membrane determine the degree of fraction exchange. Although dialysis resembles reverse osmosis, there is no concentration step in dialysis (Liguori et al., 2016).

Osmotic distillation is a beer dealcoholisation process carried out under low pressure and temperature, with low interaction between the membrane and permeate and retentate. This method has high energy efficiency compared to reverse osmosis and distillation. The disadvantage of this process is that volatile $\mathrm{CO}_{2}$ compounds are lost in the process. The selectivity of the process is determined by the equilibrium between liquid and vapor and the concentration in the system (Purwasasmita et al., 2015).

The pervaporation process uses selective semipermeable membranes to separate alcohol by diffusion in the gas phase at low temperatures. The difference in chemical potential of the separated fluids causes the alcohol molecules to be displaced and penetrate the membrane in the direction from the highest alcohol concentration to the lowest (Olmo et al., 2014).

\section{SUMMARY}

Low and non-alcoholic beers are now an integral part of the global beer market. It is worth noting that currently the consumption of alcohol-containing beer in Europe has a downward trend compared to the upward trend for LAB and NAB. In Poland, mainly NAB is growing in importance, accounting for almost $5 \%$ of the beer market value, i.e., PLN 822 million. The increased interest in NAB is due to the high nutritional and health-promoting value of beer, and the lack of alcohol allows for the development of functional beverages with potential health benefits. This direction of development of this category of beer is becoming more and more visible. NAB which is isotonic, energetic, revitalizing, or contains probiotics and xanthohumol have already appeared on the market.

The currently used biological and physical methods for the reduction of alcohol in the beer are effective and have been well established. Biological methods include modification of the mashing program in order to reduce the level of fermentable sugars in wort e.g., inactivation of $\beta$-amylase, or the use of unconventional yeasts with limited ability or inability to convert fermentable sugars (glucose, maltose, maltotriose) into alcohol. The group of physical methods includes modern thermal and membrane separation techniques which enable the efficient removal of ethanol from beer to the desired level. On the other hand, ensuring the sensory stability of low- and nonalcoholic beer is one of the main technological challenges. It requires a deep understanding of production processes, equipment, and systems. Future research 
Kozłowski, R., Dziedziński, M., Stachowiak, B., Kobus-Cisowska, J. (2021). Non- and low-alcoholic beer - popularity and manufacturing techniques. Acta Sci. Pol. Technol. Aliment., 20(3), 347-357. http://dx.doi.org/10.17306/J.AFS.2021.0961

on these beers must also focus on characterizing the raw materials and chemical composition of the beer, as well as fermenting/flavoring yeasts in order to modulate the sensory properties of beer for an increasingly demanding consumer.

Regardless of the brewing technology chosen, the brewer's primary goal is still to fulfill the wishes of the consumer, whether it be traditional beers or low- and non-alcoholic beers.

\section{REFERENCES}

Bellut, K., Krogerus, K., Arendt, E. K. (2020). Lachancea fermentati strains isolated from kombucha: Fundamental insights, and practical application in low alcohol beer brewing. Front. Microbiol., 11, 764. https://doi. org/10.3389/fmicb.2020.00764

Brányik, T., Silva, D. P., Baszczyňski, M., Lehnert, R., Almeida e Silva, J. B. (2012). A review of methods of low alcohol and alcohol-free beer production. J. Food Eng., 108, 493-506. https://doi.org/10.1016/j.jfoodeng.2011.09.020

Burger, F., Zarnkow, M. (2009). Special production methods. In H. M. Eßlinger (Ed.), Handbook of brewing. Processes, technology, markets (pp. 235-256). Weinheim: Viley VCH.

Canonico, L., Agarbati, A., Comitini, F., Ciani, M. (2016). Torulaspora delbrueckii in the brewing process: A new approach to enhance bioflavor and to reduce ethanol content. Food Microbiol., 56, 45-51. https://doi. org/10.1016/j.fm.2015.12.005

Capece, A., Romaniello, R., Siesto, G., Romano, P. (2018). Conventional and non-conventional yeasts in beer production. Fermentation, 4, 38. https://doi.org/10.3390/ fermentation 4020038

De Francesco, G., Turchetti, B., Sileoni, V., Marconi, O., Perretti, G. (2015). Screening of new strains of Saccharomycodes ludwigii and Zygosaccharomyces rouxii to produce low-alcohol beer: Screening of new strains of S. ludwigii and Z. rouxii. J. Inst. Brew., 121, 113-121. https://doi.org/10.1002/jib.185

de Gaetano, G., Costanzo, S., Di Castelnuovo, A., Badimon, L., Bejko, D., Alkerwi, A., ..., Iacoviello, L. (2016). Effects of moderate beer consumption on health and disease: A consensus document. Nutr. Metabol. Cardiovasc. Dis., 26, 443-467. https://doi.org/10.1016/j.numecd.2016.03.007

de Moura, F. P. de M., dos Santos Mathias, T. R. (2018). A comparative study of dry and wet milling of barley malt and its influence on granulometry and wort composition. Beverages, 4, 51. https://doi.org/10.3390/beverages4030051

Dziedziński, M., Szczepaniak, O., Telichowska, A., Kobus-Cisowska, J. (2020). Antioxidant capacity and cholinesterase inhibiting properties of dietary infusions with Humulus lupulus. J. Elem., 25, 657-673. https:// doi.org/10.5601/jelem.2020.25.1.1913

Eßlinger, H. M. (2009). Fermentation, maturation and storage. In H. M. Eßlinger (Ed.), Handbook of brewing, processes, technology, markets (pp. 207-224). Weinheim: Wiley VCH.

Eurostat (2020). Happy International Beer Day! https:// ec.europa.eu/eurostat/en/web/products-eurostat-news/-/ edn-20200807-1.

Floridi, S., Montanari, L., Marconi, O., Fantozzi, P. (2003). Determination of free phenolic acids in wort and beer by coulometric array detection. J. Agric. Food Chem., 51, 1548-1554. https://doi.org/10.1021/jf0260040

Gościnna, K., Pobereżny, J., Wszelaczyńska, E., Świerczyński, K., Łaba, S. (2019). Projektowanie funkcjonalnych piw rzemieślniczych o właściwościach prozdrowotnych. Przem. Spoż., 73, 64-70. http://yadda.icm.edu.pl/yad$\mathrm{da} /$ element/bwmeta1.element.baztech-891cb01f-8fa9-438f-9711 4b38585ada26

Habschied, K., Lončarić, A., Mastanjević, K. (2020). Screening of polyphenols and antioxidative activity in industrial beers. Foods, 9, 238. https://doi.org/10.3390/ foods 9020238

Holt, S., Mukherjee, V., Lievens, B., Verstrepen, K. J., Thevelein, J. M. (2018). Bioflavoring by non-conventional yeasts in sequential beer fermentations. Food Microbiol., 72, 55-66. https://doi.org/10.1016/j. fm.2017.11.008

Ignat, M. V., Salanță, L. C., Pop, O. L., Pop, C. R., Tofană, M., Mudura, E., ..., Pasqualone, A. (2020). Current functionality and potential improvements of non-alcoholic fermented cereal beverages. Foods, 9, 1031. https://doi. org/10.3390/foods 9081031

Jaskula-Goiris, B., Goiris, K., Syryn, E., Van Opstaele, F., De Rouck, G., ..., De Cooman, L. (2014). The use of hop polyphenols during brewing to improve flavor quality and stability of Pilsner beer. J. Am. Soc. Brew. Chem., 72, 175-183. https://doi.org/10.1094/ASBCJ-2014-0616-01

Kawa-Rygielska, J., Adamenko, K., Kucharska, A. Z., Prorok, P., Piórecki, N. (2019). Physicochemical and antioxidative properties of Cornelian cherry beer. Food Chem., 281, 147-153. https://doi.org/10.1016/j.foodchem.2018.12.093 
Kozłowski, R., Dziedziński, M., Stachowiak, B., Kobus-Cisowska, J. (2021). Non- and low-alcoholic beer - popularity and manufacturing techniques. Acta Sci. Pol. Technol. Aliment., 20(3), 347-357. http://dx.doi.org/10.17306/J.AFS.2021.0961

Kirin Holdings Company (2020). Global beer consumption by country in 2019. https://www.kirinholdings.co.jp/ english/news/2020/1229_01.pdf.

Kołota, A., Oczkowski, M., Gromadzka-Ostrowska, J. (2014). Wpływ występujących w piwie związków polifenolowych na organizm - przegląd literatury [Influence of beer polyphenolic compounds on the organism - a review]. Alcoh. Drug Addict., 27, 273-281 [in Polish]. https://doi.org/10.1016/S0867-4361(14)70020-3

Kowalczuk, I., Jeżewska-Zychowicz, M., Trafiałek, J. (2017). Conditions of honey consumption in selected regions of Poland. Acta Sci. Pol. Technol. Aliment., 16, 101-112. https://doi.org/10.17306/J.AFS.2017.2017.0446

Liguori, L., De Francesco, G., Russo, P., Perretti, G., Albanese, D., Di Matteo, M. (2016). Quality attributes of low-alcohol top-fermented beers produced by membrane contactor. Food Bioproc. Technol., 9, 191-200. https://doi.org/10.1007/s11947-015-1612-y

Martínez, A., Vegara, S., Herranz-López, M., Martí, N., Valero, M., Micol, V., Saura, D. (2017). Kinetic changes of polyphenols, anthocyanins and antioxidant capacity in forced aged hibiscus ale beer: Kinetic changes of polyphenols, anthocyanins and antioxidant capacity in forced aged hibiscus ale beer. J. Inst. Brew., 123, 58-65. https://doi.org/10.1002/jib.387

Mellor, D. D., Hanna-Khalil, B., Carson, R. (2020). A review of the potential health benefits of low alcohol and alcohol-free beer: Effects of ingredients and craft brewing processes on potentially bioactive metabolites. Beverages, 6, 25. https://doi.org/10.3390/beverages6020025

Michel, M., Meier-Dörnberg, T., Jacob, F., Methner, F.-J., Wagner, R. S., Hutzler, M. (2016). Review: Pure nonSaccharomyces starter cultures for beer fermentation with a focus on secondary metabolites and practical applications: Non-conventional yeast for beer fermentation. J. Inst. Brew., 122, 569-587. https://doi.org/ 10.1002/jib.381

Mikyška, A., Dušek, M. (2019). How wort boiling process affects flavonoid polyphenols in beer. Kvasn. Prum., Ferm. Ind., 65(6), 192-200. https://doi.org/10.18832/ kp2019.65.192

Montanari, L., Marconi, O., Mayer, H., Fantozzi, P. (2008). Production of alcohol-free beer. In V. R. Preedy (Ed.), Beer in health and disease prevention (pp. 61-75). London: Academic Press.

Muller, C., Neves, L. E., Gomes, L., Guimarães, M., Ghesti, G. (2020). Processes for alcohol-free beer production: a review. Food Sci. Technol., 40, 273-281. https://doi. org/10.1590/fst.32318
Olmo, Á. del, Blanco, C. A., Palacio, L., Prádanos, P., Hernández, A. (2014). Pervaporation methodology for improving alcohol-free beer quality through aroma recovery. J. Food Eng., 133, 1-8. https://doi.org/10.1016/j. jfoodeng.2014.02.014

Pielak, M., Czarniecka-Skubina, E., Trafiałek, J., Głuchowski, A. (2019). Contemporary trends and habits in the consumption of sugar and sweeteners - A questionnaire survey among poles. Int. J. Envir. Res. Public Health, 16, 1164. https://doi.org/10.3390/ijerph16071164

Pietro, M. B., Bamforth, C. W. (2011). A comparison of the antioxidant potential of wine and beer. J. Inst. Brew., 117, 547-555. https://doi.org/10.1002/j.2050-0416.2011. tb00503.x

Puerari, C., Strejc, J., Souza, A. C., Karabín, M., Schwan, R. F., Brányik, T. (2016). Optimization of alcohol-free beer production by lager and cachaça yeast strains using response surface methodology: Optimization of alcoholfree beer production. J. Inst. Brew., 122, 69-75. https:// doi.org/10.1002/jib.306

Purwasasmita, M., Kurnia, D., Mandias, F. C., Khoiruddin, Wenten, I. G. (2015). Beer dealcoholization using nonporous membrane distillation. Food Bioprod. Proc., 94, 180-186. https://doi.org/10.1016/j.fbp.2015.03.001

Rošul, M., Mandić, A., Mišan, A., Derić, N., Pejin, J. (2019). Review of trends in formulation of functional beer. Food Feed Res., 46, 23-35. https://doi.org/10.5937/ FFR1901023R

Saison, D., De Schutter, D. P., Vanbeneden, N., Daenen, L., Delvaux, F., Delvaux, F. R. (2010). Decrease of aged beer aroma by the reducing activity of brewing yeast. J. Agric. Food Chem., 58, 3107-3115. https://doi.org/ 10.1021/jf9037387

Salanţă, L., Tofană, M., Pop, C., Pop, A., Coldea, T., Mihai, M. (2018). Risk factors associated with alcohol consumption among Romanian university students Preliminary research. Bull. Univ. Agric. Sci. Vet. Med. Cluj-Napoca, Food Sci. Technol., 75, 86-89.

Salanță, L. C., Coldea, T. E., Ignat, M. V., Pop, C. R., Tofană, M., Mudura, E., ..., Zhao, H. (2020). Non-alcoholic and craft beer production and challenges. Processes, 8, 1382. https://doi.org/10.3390/pr8111382

Sohrabvandi, S., Mousavi, S. M., Razavi, S. H., Mortazavian, A. M., Rezaei, K. (2010). Alcohol-free beer: Methods of production, sensorial defects, and healthful effects. Food Rev. Int., 26, 335-352. https://doi.org/10.1 080/87559129.2010.496022

Szollosi, A., Nguyen, Q. D., Kovacs, A. G., Fogarasi, A.-L., Kun, S., Hegyesne-Vecseri, B. (2016). Production of low or non-alcoholic beer in microbial fuel cell. Food 
Kozłowski, R., Dziedziński, M., Stachowiak, B., Kobus-Cisowska, J. (2021). Non- and low-alcoholic beer - popularity and manufacturing techniques. Acta Sci. Pol. Technol. Aliment., 20(3), 347-357. http://dx.doi.org/10.17306/J.AFS.2021.0961

Bioprod. Proc., 98, 196-200. https://doi.org/10.1016/j. fbp.2016.01.012

USDA (2019a). Alcoholic beverage, beer, regular, all. U.S. Department of Agriculture. https://fdc.nal.usda.gov/fdcapp.html\#/food-details/168746/nutrients

USDA (2019b). Malt beverage, includes non-alcoholic beer. U.S. Department of Agriculture. https://fdc.nal.usda. gov/fdc-app.html\#/food-details/174863/nutrients

Ustawa z 26 października 1982 r. o wychowaniu w trzeźwości i przeciwdziałaniu alkoholizmowi [Act of October 26, 1982 on upbringing in sobriety and counteracting alcoholism] (1982). Dz.U. 1982, nr 35, poz. 230 z późn. zm. [in Polish]. https://isap.sejm.gov.pl/isap.nsf/ DocDetails.xsp?id=WDU19820350230

Vanderhaegen, B., Neven, H., Coghe, S., Verstrepen, K. J., Derdelinckx, G., Verachtert, H. (2003). Bioflavoring and beer refermentation. Appl. Microbiol. Biotechnol., 62, 140-150. https://doi.org/10.1007/s00253-003-1340-5

Violino, S., Figorilli, S., Costa, C., Pallottino, F. (2020). Internet of beer: A review on smart technologies from mash to pint. Foods, 9(7), 950. https://doi.org/10.3390/ foods 9070950
Wannenmacher, J., Cotterchio, C., Schlumberger, M., Reuber, V., Gastl, M., Becker, T. (2019). Technological influence on sensory stability and antioxidant activity of beers measured by ORAC and FRAP. J. Sci. Food Agric., 99, 6628-6637. https://doi.org/10.1002/jsfa.9979

Woźniak, B. (2013). Browary robią co mogą i walczą na radlery [Breweries are doing what they can and are fighting on radlers; in Polish]. https://www.portalspozywczy. $\mathrm{pl} /$ alkohole-uzywki/wiadomosci/browary-robia-co-moga-i-walcza-na-radlery, 88949.html

Zhao, H., Chen, W., Lu, J., Zhao, M. (2010). Phenolic profiles and antioxidant activities of commercial beers. Food Chem., 119, 1150-1158. https://doi.org/10.1016/j. foodchem.2009.08.028

0\% alkoholu 100\% smaku. Raport Kompanii Piwowarskiej o piwach bezalkoholowych w 2020 roku [0\% alcohol $100 \%$ taste. Kompania Piwowarska Report on non-alcoholic beers in 2020] (2020). Kompania Piwowarska [in Polish]. https://www.kp.pl/files/cms/1606388039_0_ 